\title{
SMART SPECIALIZATION STRATEGY MONITORING: THE BIOECONOMY
}

Sergejs Gemma ${ }^{1}$, MPA; Zane Vitolina², Dr.oec.

1,2 Latvia University of Life Sciences and Technologies

\begin{abstract}
To achieve the goal of the Latvia 2030 strategy - to be the leader in the EU in terms of preservation, replenishment and sustainable exploitation of natural capital - , it is required to address the role of the bioeconomy in Latvia. In order for the Bioeconomy Strategy of Latvia 2030 (LIBRA strategy) of Latvia to be sustainable and ensure efficient use of natural resources, it is necessary to apply an integrated approach to knowledge-based growth as well as to symbiotically integrate the other areas into agriculture, forestry and fisheries, observing the basic principles of a circular (sustainable) economy. Accordingly, under the Bioeconomy Strategy of Latvia 2030 the rural areas and regions have prospects for development. The research aim is to identify the proportion of the bioeconomy in the economy of Latvia at municipality level.
\end{abstract}

Key words: smart specialization strategy, bioeconomy, innovation.

JEL code: R11; O31; P48.

\section{Introduction}

The existence of a national strategy for smart specialization is an ex ante conditionality for the use of the European Union (EU) Structural Funds from 2014 to 2020. The aim of the strategy in Europe is to become competitive in the global economy by concentrating resources in research and innovation (R\&I) and linking them to priority economic areas. The main aim of the smart specialization strategy (RIS3) in Latvia is to increase innovation capacity and to create an innovation system that promotes and supports technological progress in the economy (Informativais zinojums „Par ..., 2013). RIS3 is a strategy of economic transformation towards higher added value, more efficient use of resources, specialisation of the existing resources of territories. According to the previous research studies (Gemma, Vitolina, 2017; 2018), Research and Innovation Strategy for Smart Specialisation (RIS3)-based overall growth (in national priority areas) is quite vague, as No total correlation and effects on the national economy are observed.

The research examined the situation at bioeconomy enterprises (as one the RIS3 knowledge specialization areas is Knowledge-intensive bio-economics) by employing the latest available data Lursoft data for 2017.

Lursoft is a database providing data of the information system of the Register of Enterprises in Latvia. It provides access to the general national legal information database and also supplies a range of services. The authors used data on industries and economic sectors. The data selected allowed identifying the main change in the growth of bioeconomy industries in municipalities and cities.

The research aim is to identify the proportion of the bioeconomy in the economy of Latvia, based on the number of enterprises in municipality level. The specific research tasks are as follows: 1) to identify the number of enterprises engaged in the bioeconomy in 2017; 2) to calculate the proportions of bioeconomy enterprises in the total enterprises in the municipalities of Latvia; 3) to analyse the situation in accordance to the tendencies of the innovative entrepreneurship as one of the RIS3 overall goals.

The research employed the following methods: monographic, comparison, the graphical method and statistical analysis. The data acquired in the National Research Program 5.2. "Economic Transformation, Smart Growth, Governance and Legal Framework for the State and Society for Sustainable Development - a New Approach to the Creation of a Sustainable Learning Community (EKOSOC-LV)". 


\section{Research results and discussion}

The Sustainable Development Strategy of Latvia until 2030 (Latvia 2030) states that in Latvia, natural capital is in relatively good condition, yet it is insufficiently efficiently exploited and managed. To achieve the goal of the Latvia 2030 strategy - to be the leader in the EU in terms of preservation, replenishment and sustainable exploitation of natural capital - , it is required to address the role of the bioeconomy in Latvia. This issue is included both in the Smart Specialization Strategy (RIS3) measures and The Bioeconomy Strategy of Latvia 2030 (LIBRA strategy).

LIBRA strategy envisages the promotion and preservation of employment in the bioeconomy industries, higher value-added of bioeconomic products and an increase in exports of the bioeconomic products.

The bioeconomy is part of the national economy that exploits renewable sources to produce food and feed, industrial products and energy in a sustainable and prudent way (European Commission, 2012). The bioeconomy industries are agriculture, fisheries, food manufacturing, forestry, woodprocessing, pulp and paper manufacturing as well as some segments of the chemical industry, the energy industry and the biotechnology industry. The world's population is projected to increase, resulting in higher market demand, yet at present, the consumption of resources by mankind exceeds the capacity of the Earth to renew the resources in a sustainable way. This leads to global dependence on fossil resources, which could be reduced by broader use of bioresources and replacement of the fossil resources. The global demand for bioresources is surely projected to increase (Muller et al., 2007).

Being aware of the importance of bioeconomic development, more than 50 world countries, to a greater or smaller extent, support and contribute to bioeconomic development by means of various programmes, strategies, action plans and other policy documents. Most of these countries are EU Member States. In 2012, the EU designed a bioeconomy strategy Innovation for Sustainable Growth: a Bioeconomy for Europe and actively promotes growth in this sector.

Accordingly, one more way how Latvia can distinguish this specialisation and make it a priority of the national economy is the European Union Smart Specialisation Strategy whereby the country can nationally prioritise the areas it is going to specialise at the EU level in the future in order to develop the national economic environment in conjunction with other areas. To induce the change and growth the RIS3 has outlined seven investment priorities and defined five specialization areas in Latvia. The investment priorities are: 1) High added value products; 2) Productive Innovation System; 3) Energy Efficiency; 4) Modern ICT; 5) Modern education; 6) The knowledge base; 7) Polycentric development. The knowledge specialization areas are: 1) Knowledge-intensive bio-economics; 2) Biomedicine, medical technologies, 3) Bio-pharmacy and biotechnologies; 4) Smart materials, technologies and engineering systems; smart energetics; 4) Information and communication technologies (ICT)

In Latvia, the bioeconomy encompasses many industries, which might be divided into several groups (Table 1). The first two of these groups are considered to be traditional bioeconomy sectors.

The kinds of economic activity registered by enterprises are specified by NACE codes. NACE is an abbreviation in French "Nomenclature statistique des activités économiques dans la Communauté européenne" or the standard classification of productive economic activities in the European Union. Every NACE code corresponds to some kind of business any enterprise is engaged in (What is a..., s.a.).

By selecting the industries shown in Table 1 according to the corresponding NACE codes pertaining to the bioeconomy, the authors selected enterprises operating in 2017, which allowed assessing the 
development of the bioeconomy based on the number of bioeconomy enterprises in Latvia. A comparison of the number of enterprises engaged in the bioeconomy between the RIS3 introduction year and 2017 (Table 2) revealed that the number of enterprises in the bioeconomy rose and this sectors gradually expanded.

Table 1

\section{Classification of bioeconomic activities in Latvia}

\begin{tabular}{|c|c|}
\hline Group & Economic sector and NACE code \\
\hline Bio-resources primary production & $\begin{array}{ll}\text { - } & \text { agriculture (A01) } \\
\text { - } & \text { forestry (A02) } \\
\text { - } & \text { fisheries (A03) }\end{array}$ \\
\hline $\begin{array}{l}\text { Bio-processing industry, where activity has largely } \\
\text { or completely dependent on bio-resource }\end{array}$ & $\begin{array}{l}\text { - } \quad \text { food and feed production (C10, C11, C12) } \\
\text { - } \quad \text { leather products (C15) } \\
\text { - } \text { manufacture of products of wood and of articles of } \\
\text { - } \quad \text { manufacture of furniture (C31) }\end{array}$ \\
\hline $\begin{array}{l}\text { Bio-processing industry in which bio-resources } \\
\text { competes or is an alternative to other materials }\end{array}$ & $\begin{array}{ll}\text { - } & \text { textiles }(\mathrm{C} 13, \mathrm{C} 14) \\
\text { - } & \text { chemicals }(\mathrm{C} 20) \\
\text { - } & \text { pharmaceutical industry (C21) } \\
\text { - } & \text { energy (D35) }\end{array}$ \\
\hline Service industries which based on bio-resources & $\begin{array}{ll} & \text { construction (F41, F42, F43) } \\
- & \text { catering (I56) } \\
\text { - } & \text { accommodation (I55) }\end{array}$ \\
\hline
\end{tabular}

Source: authors' construction based on Background study analysis..., 2017.

Number of enterprises in the bioeconomy in 2014 and 2017

\begin{tabular}{|c|c|c|c|}
\hline Year & Traditional & Other & In total \\
\hline 2014 & 10001 & 14829 & 24830 \\
\hline 2017 & 9948 & 15075 & 27040 \\
\hline
\end{tabular}

Source: authors' calculations based on Lursoft data

Traditional bioeconomy sectors are first two groups of Table 1 - bio-resources primary production and bio-processing industry, where activity has largely or completely dependent on bio-resource. As other enterprises are the bio-processing industry in which bio-resources competes or is an alternative to other materials and service industries which based on bio-resources.

In 2017 in Latvia, the number of enterprises engaged in the bioeconomy represented $43.6 \%$ of the total enterprises. Figure 1 shows that the most bioeconomy enterprises were located in rural areas, and the absolute leader was Varkava rural territory where $80.5 \%$ enterprises were engaged in the bioeconomy sector. Urban areas are industrialised, and the areas around the capital city Riga - are industrialised as well. The contribution of traditional bioeconomy industries - agriculture, forestry, fisheries, food manufacturing as well as wood-processing - to the production sector accounted for $54 \%$ of the total value-added of the goods-producing industries (Informativais zinojums „Latvijas..., 2017). This fact substantiates the concentration of the bioeconomy in rural areas.

Rural areas as a necessary component of living space for the population is an increasing focus both in official documents of various EU institutions and in research investigations. Both the documents and the research papers stress the necessity to enhance and maintain the viability of rural areas. The viability of rural areas is ensured by employment opportunities and the readiness of residents for active and innovative economic activity (Rivza, Kruzmetra, 2017). Development in rural areas also maintains growth in the bioeconomy nationally. 
At the same time, there is strong mono-centric development in Latvia, as concluded in the previous research studies (Gemma, Vitolina, 2017; 2018), and this creates unfavourable consequences in the environment for business in the regions.

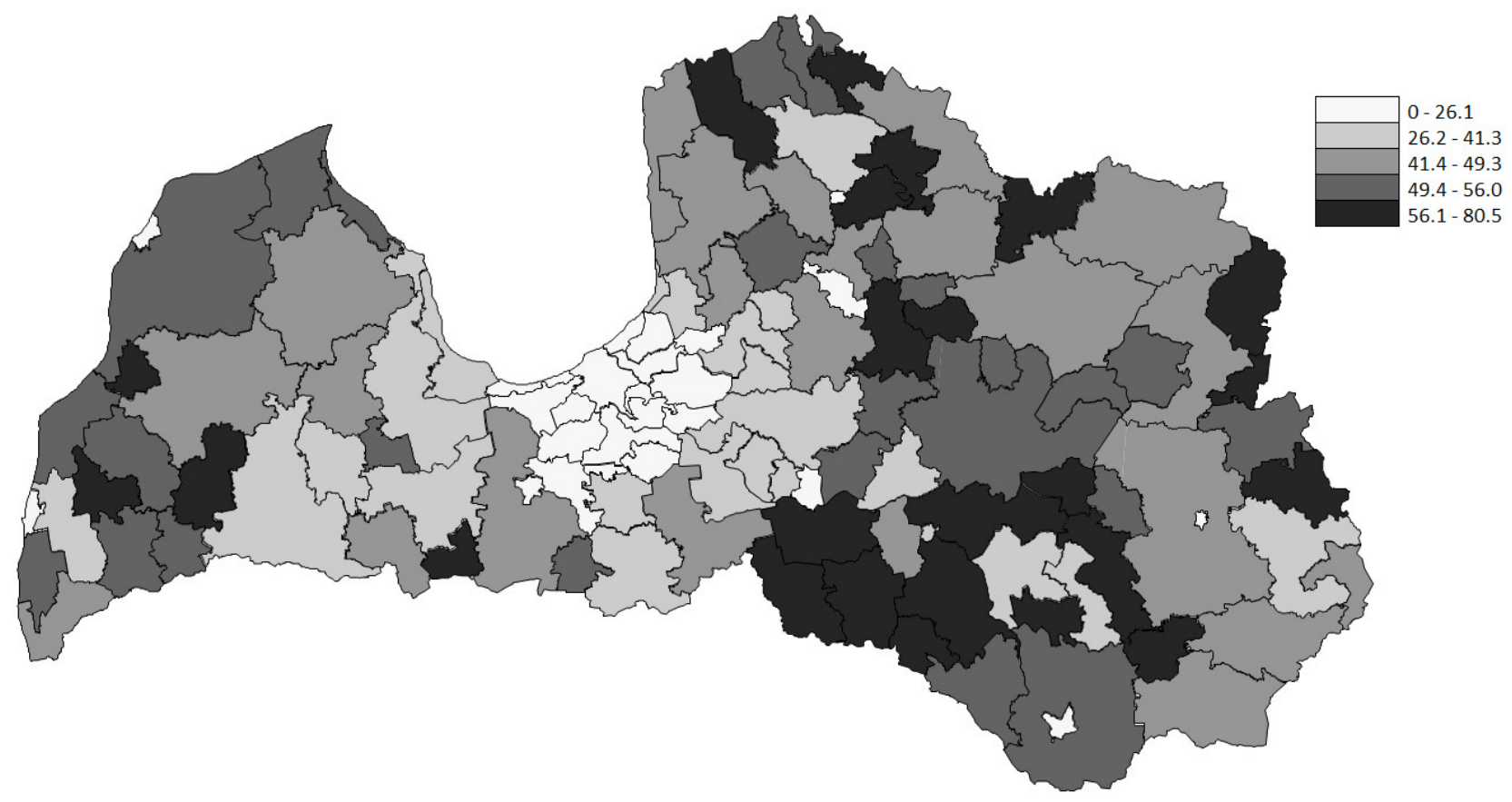

Source: authors' calculations based on Lursoft data

Fig. 1. Proportion of bioeconomy enterprises in the total enterprises in a municipality in 2017

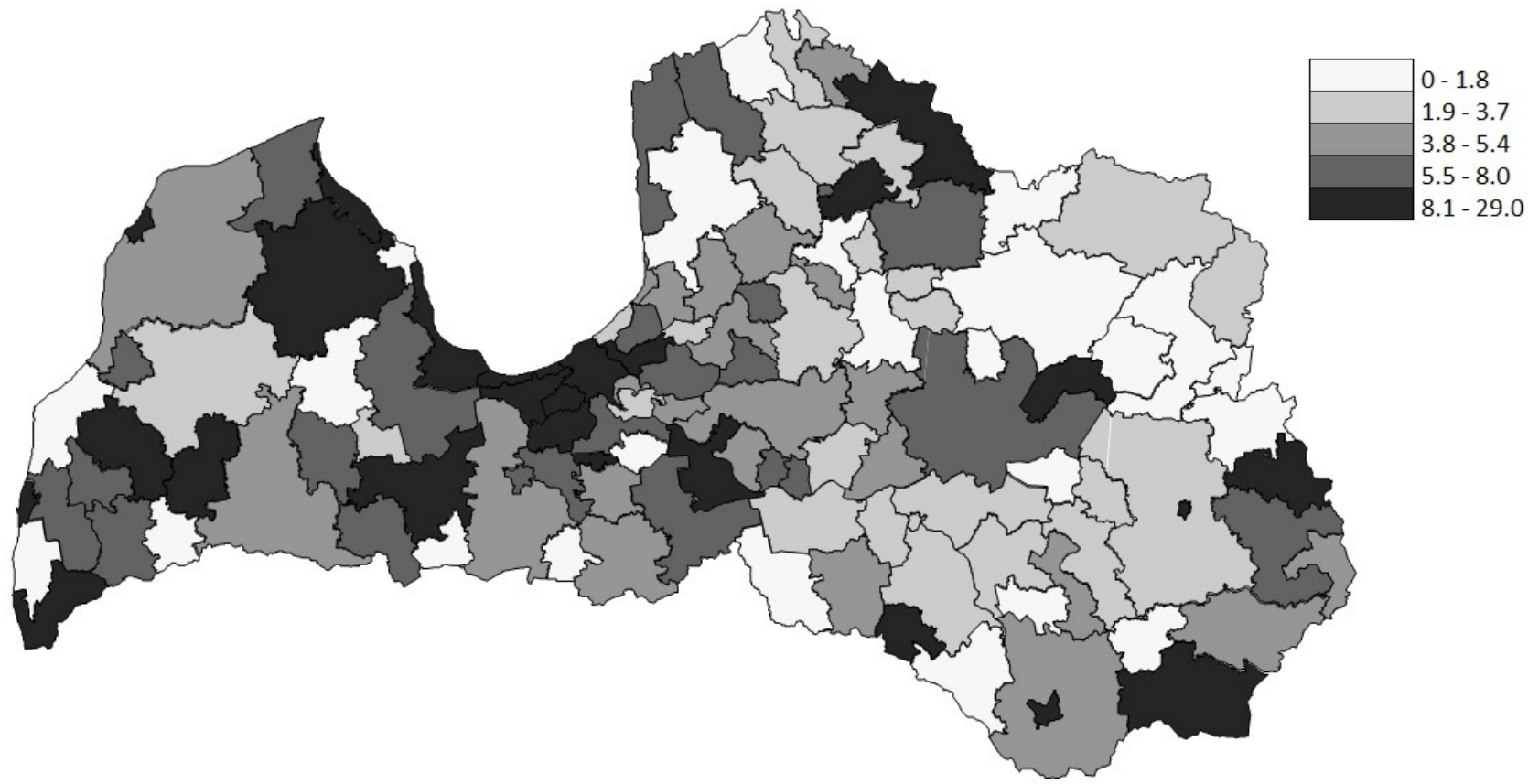

Source: authors' calculations based on Lursoft data

Fig. 2. Proportion of foreign-invested bioeconomy enterprises in the total enterprises in a municipality in $\mathbf{2 0 1 7}$

Even though the number of bioeconomy enterprises is very small in Pieriga region and major cities, foreign investments in bioeconomy enterprises in these administrative territories are considerable.

This can contribute to the one of RIS3 priorities - Identification and specialisation of the existing resources of the territories, raising prospects for economic development, and directions, including leading and prospective business directions in municipal areas. 
In 2017 in most of the municipalities, foreign investments were made in not more than $10 \%$ of the total number of bioeconomy enterprises in the municipalities, and only in Rucava municipality almost a third of bioeconomy enterprises (29\%) or 9 out of 31 had $100 \%$ foreign investment.

Although there are favourable conditions for bioeconomic development in Latvia, the current trend indicates stagnation. In 2017 compared with 2014, personal income tax revenues from the bioeconomy industries rose by $8.3 \%$ (in view of the fact that the total number of employees in the bioeconomy in the LIBRA areas in the analysis period declined by 7.4 \%, totalling 202159) (authors' calculations based on Lursoft data). This indicates that the total multiplier effect was larger and amounted to EUR 278054.6, yet this increase was insufficient to raise earnings, social guarantees and other determinant factors that would improve the overall wellbeing of bioeconomy employees. Bioeconomic development in Latvia requires a set of measures contributing to efficient use of bioresources. This is the case both for traditional bioeconomy industries that currently represent an economic pillar of the national economy and have large potential for growth and for new bioeconomy industries. Therefore, achieving the goals of the Bioeconomy Strategy involves five key integrated and complementary groups of measures:

- attractive business environment for entrepreneurship in the bioeconomy;

- result-oriented, efficient and sustainable resource management;

- knowledge and innovation development in the bioeconomy;

- promotion of production in the bioeconomy;

- socially responsible and sustainable development (Latvian Bioeconomy Strategy 2030, 2017).

RIS3 aim to foster the economic transformation of regions, building on regional competitive advantages. The planned outcome - increased capacity of innovations - includes increase in share of innovative enterprises in municipalities, shifting additional resources to both internal research and innovation capacity-building, and acquainting of technologies and knowledge on the outsourcing base in collaboration with research bodies, as well as by encouraging the formation of new innovative companies with rapid growth potential and attraction of funding in their early development phase (Knowledge capacity Assessment, 2013).

The RIS3 monitoring shows quite slow progress towards the overall goals. During the three year period (2014-2016), the number of innovative companies increased by $0.06 \%$ in high and medium high industries and by $0.71 \%$ in knowledge intense service on average. As shown in Table 2 - the number of innovative companies is decreasing in 2017 compering with 2013, indicating that RIS3 goals will not be achieved.

Table 3

RIS3 progress in Latvia

\begin{tabular}{|l|c|c|c|c|}
\hline \multicolumn{1}{|c|}{ RIS3 overall goals } & $\begin{array}{c}\mathbf{2 0 1 3} \\
\text { Base value }\end{array}$ & $\begin{array}{c}\mathbf{2 0 1 7} \\
\text { Real }\end{array}$ & Progress & $\mathbf{2 0 2 0}$ \\
\hline $\begin{array}{l}\text { Proportion of innovative companies ( \% of all } \\
\text { companies) }\end{array}$ & 30.4 & 23.4 & $66.9 \%$ & 40 \\
\hline $\begin{array}{l}\text { Proportion of high-technology and medium- } \\
\text { technology sectors in the export of Latvian gods } \\
\text { \%) }\end{array}$ & 23.8 & 31.6 & $117 \%$ & 31 \\
\hline
\end{tabular}

Source: authors' calculations

Innovation and entrepreneurship are an important component of RIS3 and territorial development. Innovative entrepreneurship is one of the decisive aspects of the overall implementation of RIS3. In analysing the innovative enterprises in the municipalities of Latvia and comparing the situation with previous Figures one can conclude that those municipalities with high share of enterprises in bioeconomy have smaller share of innovative enterprises. In 2016 there was 
one municipality with zero innovative enterprises and 26 municipalities were number of innovative companies were less than 10 (in comparison - in 2014 there were 31 municipalities with less than 10 innovative enterprises).
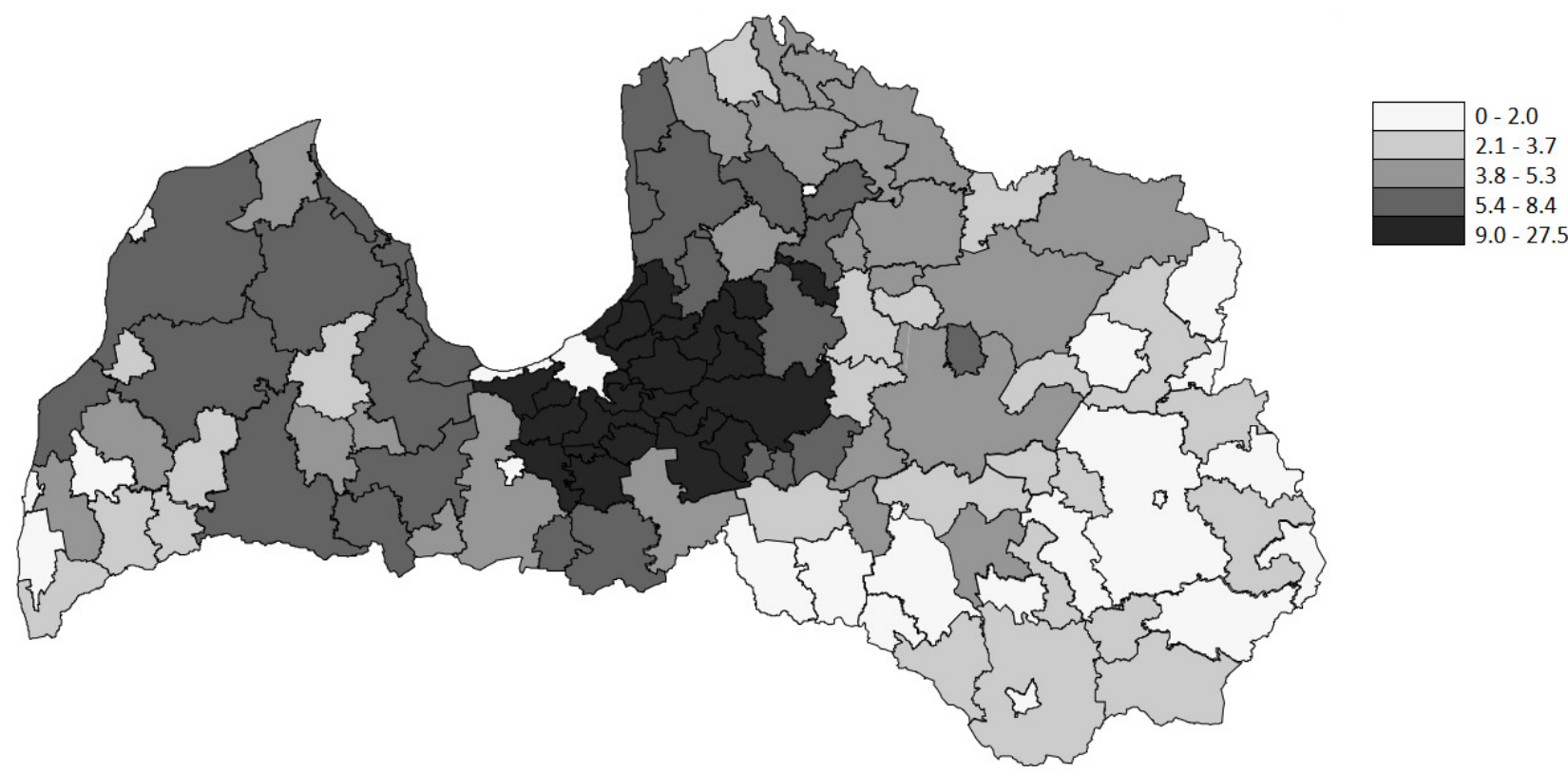

Source: authors' construction

Fig. 3. Share of innovative enterprises in the total number of enterprises in municipalities, 2016, \%

This suggest that there is a lack of innovations in these municipalities that can lead to the stagnation in terms of sustainable development and economic growth. On the other hand - if municipalities will be able to foster the effective use of natural resources, implement principles of circular economics and focus on knowledge-based development, the specialization in bioeconomics can result in sustainable development. Figure 1 and Figure 3 shows the municipalities with the emphasis on bioeconomy have low levels of innovation.

\section{Conclusions, proposals, recommendations}

1) The bioeconomy is part of the national economy that exploits renewable sources. The global demand for bioresources is surely projected to increase due to increasing population so there is a necessity to increase bioeconomy development. Bioeconomic development is mainly associated with the production, regeneration and efficient processing of bioresources. Exact the development of rural areas maintains growth in the bioeconomy nationally.

2) In Latvia in three-year period (2014-2017) the bioeconomy is slowly being developed. In 2017 in Latvia, the number of enterprises engaged in the bioeconomy represented $43.6 \%$ of the total enterprises. However, bioeconomic development in Latvia requires a set of measures contributing to efficient use of bioresources.

3) Even though the number of bioeconomy enterprises is very small in Pieriga region and major cities, foreign investments in bioeconomy enterprises in these administrative territories are considerable.

4) The RIS3 monitoring shows quite slow progress towards the overall goals. The progress towards the innovation is insufficient and there is high possibility that in 2020 the planned goals will not be achieved, and Latvia will score low on the European innovation scoreboard threatening sustainable development and economic growth. 
5) The low level and monocentric trend of innovations in Latvia shows that there are significant weaknesses in the existing innovation system. The municipalities with the emphasis on bioeconomy have low levels of innovation. Strengthening the innovation capacity will improve the bad situation about monocentric development in Latvia. Also the regional policy must be priority in next policy planning period to stabilise the uneven development and foster balanced and more harmonised development of regions and country at all.

\section{Bibliography}

1. Background Study Analysis for National Bioeconomy Strategy (2017). Retrieved: https://www.interregeurope.eu/fileadmin/user_upload/tx_tevprojects/library/file_1504269344.pdf Access: 28.12.2018.

2. European Commission (2012). Innovating for Sustainable Growth: A Bioeconomy for Europe. p. 64. Retrieved: https://publications.europa.eu/en/publication-detail/-/publication/1f0d8515-8dc0-4435-ba539570e47dbd51 access:28.12.2018.

3. Gemma S., Vitolina Z. (2018). Smart Specialisation Development in Latvia. 24th Annual International Scientific Conference Research for Rural Development Jelgava, Latvia (accepted for publication).

4. Gemma, S., Vitolina, Z. (2017) Smart specialization strategy in Latvia, Estonia and Lithuania. Economic Science for Rural Development, 45, 71-78.

5. Informativais zinojums "Latvijas Bioekonomikas strategija 2030" (Latvian Bioeconomy Strategy 2030: informative report). (2017). Retrieved: $\mathrm{http}: / /$ tap.mk.gov.lv/lv/mk/tap/?pid=40433525\&mode=mk\&date=2017-12-19 Access: 22.01.2019.

6. Informativais zinojums "Par viedas specializacijas strategijas izstradi" (Development of a Smart Specialization Strategy for Latvia: informative report). (2013). Retrieved: http://tap.mk.gov.lv/mk/tap/?pid=40291636 Access: 28.12.2018.

7. Knowledge Capacity Assessment (2013). Ministry of Education and Science. Retrieved: http://www.izm.gov.Iv/en/Science/smart-specialisation-strategy Access: 12.11.2018.

8. Latvija 2030 (2019). Retrieved: http://www.pkc.gov.lv/lv/valsts-attistibas-planosana/latvijas-ilgtspejigasattistibas-strategija Access: 22.01.2019.

9. Muller A., Schmidthuber J., Hoogeveen J., Steduto p. (2007) Some Insights in the Effect of Growing Bioenergy Demand on Global Food Security and Natural Resources. Paper presented at the International Conference: "Linkages between Energy and Water Management for Agriculture in Developing Countries", Hyderabad, India, 28-31 January 2007. Retrieved: http://www.globalbioenergy.org/uploads/media/0701_FAO_Mueller__ -

Some_insights_in_the_effect_of_growing_bioenergy_demand_on_global_food_security_and_natural_resou rces_01.pdf Access: 28.12.2018.

10. Latvian Bioeconomy Strategy 2030 (2017). Short Summary. Retrieved: https://www.Ilu.Iv/sites/default/files/2018-07/Latvian-Bioeconomy-Strategy-Summary-WEB_0.pdf Access: 26.12.2018.

11. Rivza B., Kruzmetra M. (2017). Through Economic Growth to the Viability of Rural Space. Entrepreneurship and Sustainability Issues, Entrepreneurship and Sustainability Center, 2017, 5 (2), .283- 296.

12. What is a NACE code? Retrieved: https://siccode.com/en/pages/what-is-a-nace-code Access: 25.01.2018. 